\title{
Vallen en opstaan
}

Citation for published version (APA):

Brouwer, W. (1986). Vallen en opstaan. Maastricht University. https://doi.org/10.26481/spe.19860923wb

Document status and date:

Published: 23/09/1986

DOI:

10.26481/spe.19860923wb

Document Version:

Publisher's PDF, also known as Version of record

\section{Please check the document version of this publication:}

- A submitted manuscript is the version of the article upon submission and before peer-review. There can be important differences between the submitted version and the official published version of record.

People interested in the research are advised to contact the author for the final version of the publication, or visit the DOI to the publisher's website.

- The final author version and the galley proof are versions of the publication after peer review.

- The final published version features the final layout of the paper including the volume, issue and page numbers.

Link to publication

\footnotetext{
General rights rights.

- You may freely distribute the URL identifying the publication in the public portal. please follow below link for the End User Agreement:

www.umlib.nl/taverne-license

Take down policy

If you believe that this document breaches copyright please contact us at:

repository@maastrichtuniversity.nl

providing details and we will investigate your claim.
}

Copyright and moral rights for the publications made accessible in the public portal are retained by the authors and/or other copyright owners and it is a condition of accessing publications that users recognise and abide by the legal requirements associated with these

- Users may download and print one copy of any publication from the public portal for the purpose of private study or research.

- You may not further distribute the material or use it for any profit-making activity or commercial gain

If the publication is distributed under the terms of Article $25 \mathrm{fa}$ of the Dutch Copyright Act, indicated by the "Taverne" license above, 


\section{श는 Rijksuniversiteit Limburg}

Bibliotheek

Postbus $616 \quad 6200$ MD Mastricht

Dit werk terugbezorgen voor

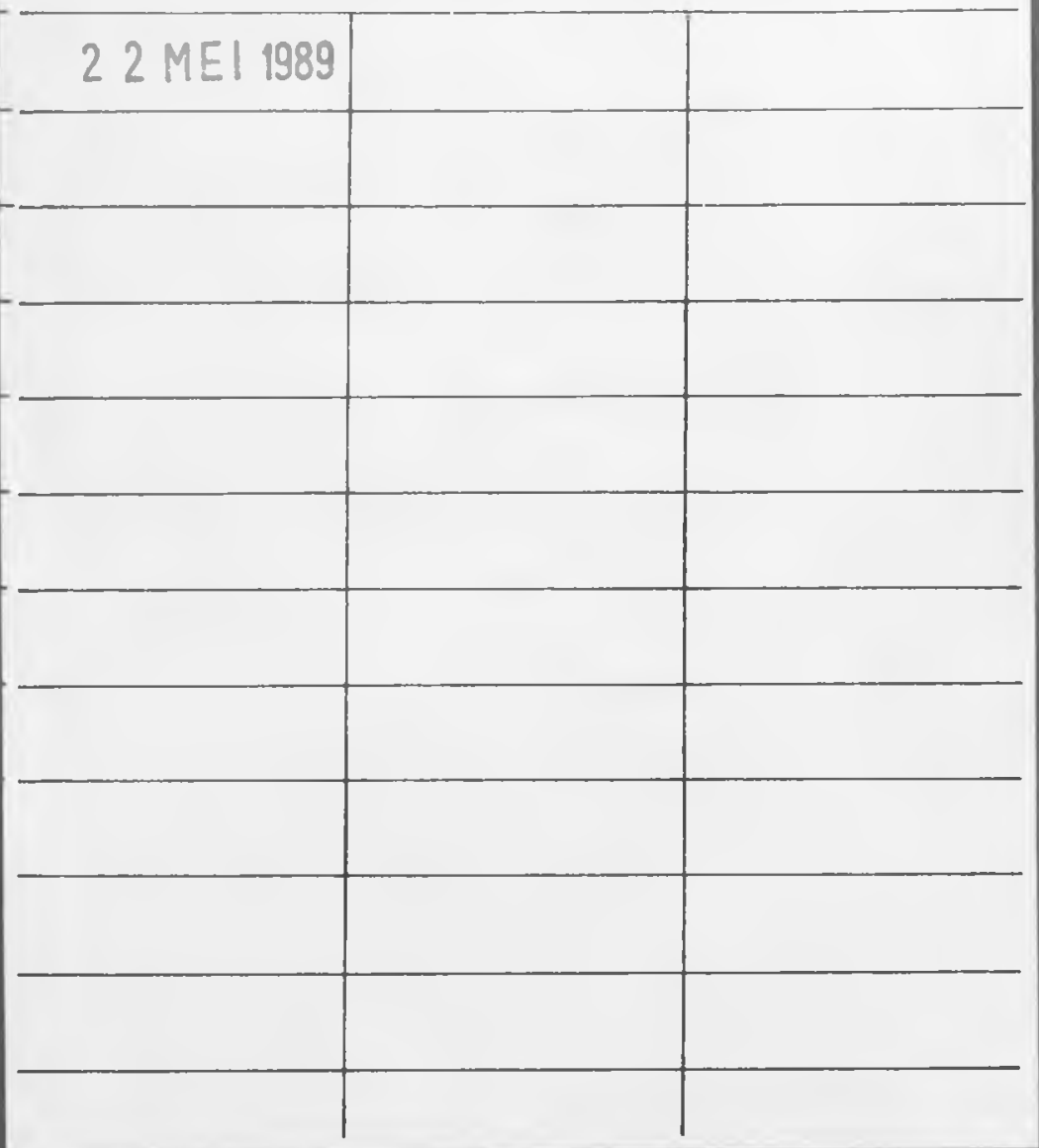




\section{VALLEN EN OPSTAAN}

Oratie ter gelegenheid van het afscheid van de Faculteit der Geneeskunde van de Rijksuniversiteit Limburg gehouden door

Prof. Dr. W. Brouwer

Maastricht 23 september 1986 
Blbliotheek

R.U.Limburg

$906 \cdot 0 \cdot 20.220$ 
Hooggeachte bestuurders van de Rijksuniversiteit Limburg. Hooggeachte Rector en College van Dekanen.

Hooggeachte collegae, docenten en studenten en $U$ allen, zeer gewaardeerde toehoorders, die door uw aanwezigheid blijk geeft van Uw belangstelling.

\section{Valkuilen in de huisartspraktijk.}

Wanneer we de Romeinse staatsman en literator Cicero mogen geloven, dan was het Dionysios de Oudere die boven het hoofd van zijn hoveling Damocles een zwaard liet ophangen aan een paardehaar. Deze, zo niet kwaadaardige dan toch op zijn minst merkwaardige maatregel nam hij omdat hij op indringende wijze aan Damocles duidelijk wilde maken dat een regerend vorst voortdurend bloot staat aan gevaar.

De symbolische betekenis die de uitdrukking "het zwaard van Damocles" heeft gekregen is van toepassing op velen, in die zin dat ze bij de uitoefening van hun beroep iets dergelijks ook boven hun hoofd voelen. Menige huisarts kent dat gevoel. Als zwaard van Damocles ervaart hij vooral de kans dat op een of ander moment een ernstige ziekte of een gevaarlijke ontwikkeling van een reeds bekende ziekte niet of niet tijdig door hem wordt onderkend met daaropvolgend - post of propter - een catastrofale ontwikkeling voor de patient en daaraan gekoppeld eveneens voor de huisarts. Het besef van de aanwezigheid van die koppeling heeft ook een gunstige kant. In de luchtvaart bijvoorbeeld realiseert men zich dat de veiligheid van het luchtverkeer voor een belangrijk deel steunt op het feit dat een gezagvoerder van een vliegtuig in gelijke mate als zijn passagiers vitaal belang heeft bij een veilig verloop van de vlucht. Misschien is het niet voor niets dat piloten nog al eens spreken over hun kist, als ze het over hun vliegtuig hebben.

Huisartsen weten evenals piloten dat waakzaamheid geboden is, in het belang van de patient en in het belang van hen zelf. Daarnaast heerst echter bij hen het gevoel dat ze ondanks nauwgezet en gewetensvol werken gevaar lopen vroeg of laat verzeild te raken in een dramatische situatie, waarbij het paardehaar breekt, het zwaard naar beneden valt en waarbij zowel de huisarts als de patient letsel oploopt.

Mocht, dames en heren, deze beschrijving op $U$ afkomen als een ietwat overtrokken voorstelling van zaken dan zou ik $U$ de boekjes 
getiteld 'Valkuilen in de huisartspraktijk I en II' ter lezing willen aanbevelen. In die boekjes beschrijven in totaal vijfentwintig huisartsen elk een door hen zelf ervaren dramatisch voorval; vijfentwintig korte verhalen waarin wordt beschreven hoe het paardehaar brak en het zwaard naar beneden kwam. Ik noem $U$ enkele voorbeelden:

- Een 18-jarig meisje leek evenals een van haar huisgenoten een goedaardige zomergriep te hebben; naderhand bleek dat een cerebellair haematoom de oorzaak was van haar klachten.

- Signalen van een dreigende suicide, uitgezonden door een 50jarige man bleven onontdekt tot op het moment dat de dreiging werkelijkheid was geworden.

- Een 17-jarig meisje wenste haar zwangerschap zowel voor haar moeder als voor haar huisarts verborgen te houden.

Tijdens het doktersbezoek zag ze kans het beddelaken beschermend om zich heen te houden en zo het buikonderzoek te ontgaan. Aldus slaagde de patiente er in zich niet bloot te geven met het gevolg dat enkele weken later de huisarts zelf bloot stond aan heftige verwijten van de kant van de moeder.

Opvallend is dat bijna alle auteurs zich zelf verwijten dat ze de alarmsignalen niet als zodanig hebben onderkend en dat daardoor een ziekte, een zwangerschap of een geneigdheid tot gevaarlijk handelen door hen niet werd herkend op een moment dat dat had moeten gebeuren.

In de meeste gevallen bleek menselijk falen weliswaar een rol te spelen, maar tegelijkertijd verweven te zijn met en af en toe zelfs beheerst te worden door factoren welke te maken hebben met de omstandigheden waaronder huisartsen hun beroep uitoefenen en met de gevolgde werkmethode. Daarom komen vooral dergelijke gevallen in aanmerking voor zorgvuldige analyse, want in de praktijk van de gezondheidszorg is het in dit opzicht niet anders dan in het verkeer of bij het toepassen van kernenergie. Het moge zo zijn dat wie werkt fouten maakt en dat menselijk falen niet is uit te bannen, onverlet blijft dat er alles aan moet worden gedaan om het menselijk falen en de nadelige effecten daarvan tot een minimum te reduceren.

Hoe komt het eigenlijk dat alarmsignalen die patienten met hun klachten en ziekteverschijnselen uitzenden, soms ontsnappen aan de aandacht van de huisarts ondanks aanwezige ervaring, kunde en nauwgezetheid van werken en wat zouden we er aan kunnen doen?

Het zijn vooral deze twee vragen waarmee ik me in deze oratie zal bezighouden. 


\section{Werksituatie en werkmethode.}

Gezien de reeds gesignaleerde verwevenheid met situatieve en methodische factoren ligt het voor de hand eerst de werksituatie en de werkmethode van de huisarts te bezien. Diverse huisartsen hebben dat overigens al gedaan en daarover geschreven. Met name de beschouwing van mijn in Groningen werkzame collega Bremer in het boek 'Inleiding tot de Huisartsgeneeskunde' over de diagnostische functie van de huisarts is zeer verhelderend.

Een huisarts met een praktijk van gemiddelde omvang wordt dagelijks geconfronteerd met 25 à 30 gezondheidsproblemen. Deze gezondheidsproblemen strekken zich uit tot alle sectoren van de curatieve geneeskunde; ze zijn dan ook uiteenlopend van aard en vereisen dus actuele kennis en ervaring op een breed terrein.

Ongeveer een derde deel van de aangeboden problemen is nieuw en aangezien de huisartspraktijk als regel het eerste gezondheidszorgloket is, waar de patient zich meldt, krijgt de huisarts een relatief groot aantal beginklachten voorgelegd. Die klachten zijn veelal vaag en het valt de patient vaak moeilijk deze duidelijk onder woorden te brengen.

De gezondheidsproblemen, die de huisarts ziet, zijn in overgrote meerderheid goedaardig. De bekende Engelse huisarts K. Hodgkin heeft dit op duidelijke wijze tot uitdruk- king gebracht in zijn bekende boek 'Towards earlier diagnosis'. Op grond van nauwkeurige registratie gedurende vele jaren stelde hij vast dat bijvoorbeeld de klacht diarree slechts in één van de 100 gevallen het gevolg is van een ernstige ziekteoorzaak; bij de klacht hoesten is de verhouding 1:57. Geheel anders is de verhouding bij de overigens veel minder vaak voorkomende slikklachten. De verhouding ernstig-niet-ernstig is dan 1:3. Huisartsen krijgen dus dagelijks te maken met een groot aantal gevarieerde gezondheidsproblemen. Een aanzienlijk deel daarvan verkeert nog in een beginnend, min of meer onduidelijk stadium. De kans dat de aangeboden klachten alarmsignalen zijn, d.w.z. signalen van een ernstig lijden, wisselt per klacht. De huisarts weet echter dat in het merendeel van de gevallen die kans weliswaar aanwezig, maar gering te achten is. Die omstandigheden kunnen er toe leiden dat de huisarts soms geneigd is tot een meer optimistische en minder waakzame benadering dan gewenst is.

De tijd waarop en de plaats waar huisarts en patient elkaar ontmoeten, worden vooral bij spoedgevallen en avond- resp. nachtvisites bepaald door de patient. Als gevolg daarvan kan het gebeuren dat de startpositie van waar de huisarts het consult ingaat, door tijdgebrek, gebrek aan nachtrust of 
anderszins door privé-omstandigheden niet optimaal is. Dit lijkt een triviale vaststelling van zaken. In analyses van gevallen waarin er iets mis ging blijkt evenwel bij herhaling dat dergelijke bijkomende omstandigheden van invloed zijn geweest.

Huisartsen kennen hun patienten meestal reeds geruime tijd. Ook bij nieuwe klachten gaat het als regel om patienten die vanwege andere klachten geen onbekenden meer zijn. Vroeger doorgemaakte ziekten, persoonlijke hoedanigheden, gezinssituatie, beroepsuitoefening, doorgaans is de huisarts over dit alles redelijk georiënteerd. Hij heeft veelal een hoeveelheid voorkennis en er is al een relatie. Beide komen bij de hulpverlening doorgaans goed van pas, maar ze kunnen de huisarts ook op een dwaalspoor brengen. Voorafgaande ervaringen, mededelingen van andere huisartsen, opinies van specialisten, suggestieve formuleringen van familieleden of van de patient zelf beinvloeden de huisarts vaak zonder dat deze het zich bewust is. Aldus beïnvloed raakt hij snel op een dwaalspoor. In genoemde gevalsbeschrijvingen zijn diverse voorbeelden hiervan te vinden.

Een huisarts, die bij een van zijn patienten, de signalen van een dreigend hartinfarct miskende, schreef daarover het volgende:

"Vanuit een misplaatst en gevaar- lijk vooroordeel beoordeelde ik de klachten die hij vlak voor zijn dood uitte. Er zijn genoeg redenen aan te voeren, die mij tot dat vooroordeel brachten, maar het belemmerde uiteindelijk op een cruciaal moment een eerlijke beoordeling". Tot zover de werksituatie. Bezien we thans de werkmethode van de huisarts. Deze komt, zij het met accentverschillen, in grote lijnen overeen met de klinische werkmethode. Met behulp van anamnese en lichamelijk onderzoek verschaft hij zich gegevens. Op basis daarvan en op basis van reeds aanwezige kennis en ervaring komt hij tot een diagnostische conclusie of veronderstelling, zijnde uitgangspunt van het therapeutisch handelen.

Bepalen we ons voorlopig even tot deze, zoals we straks zullen zien, al te simpele voorstelling van zaken.

Het anamnestische gesprek is een belangrijk kompas. De betrouwbaarheid van de kompas staat evenwel onder druk o.a. door taalproblematiek. Wat bedoelt een patient eigenlijk als hij zegt dat hij zich beroerd voelt, licht in het hoofd is of last van benauwdheid heeft? Ondanks aanvullende vragen blijft het gevaar bestaan dat de patient wordt misverstaan of slechts half wordt verstaan. Een tweede factor waarmee de huisarts tijdens het anamnestisch gesprek rekening heeft te houden is de invloed die 
hij zelf op de patient uitoefent. Wat een patient meedeelt, hoe hij het meedeelt, wat een patient verzwijgt, bagatelliseert of benadrukt wordt mede bepaald door het gedrag van de arts. Met andere woorden, het anamnestisch gesprek is een kompas, maar niet in die zin dat het gegevens levert onafhankelijk van degene die het kompas hanteert.

Ook bij het lichamelijk onderzoek is de kans dat er fouten worden gemaakt, natuurlijk aanwezig. Meestal is het de onvolledigheid van onderzoek die dan parten speelt. Bovendien spelen behalve de reeds genoemde beïnvloeding doorvoorafgaande ervaringen triviale factoren als gehaastheid van de arts of niet te vergeten afwerend gedrag van de patient nog al eens een rol.

In geval van onvolledig onderzoek blijken bepaalde onderdelen van het lichamelijk onderzoek eerder te worden nagelaten dan andere. Het meten van de bloeddruk bijvoorbeeld is een handeling die bij veel patienten wordt toegepast. Neurologisch onderzoek daarentegen lijkt nog al eens ten onrechte achterwege te blijven. Bij een evaluatie-onderzoek gericht op de resultaten van eenmalig geriatrische consulten, viel mij op dat bij een aantal van deze geriatrische patienten een neurologisch onderzoek voor de hand lag, maar niet was uitgevoerd.
Een volgende bron van fouten is de verwerking van de via anamnese en onderzoek verkregen gegevens. De reeds gesignaleerde beinvloeding door voorafgaande ervaringen speelt juist hier een grote rol. Daarnaast is er de moeilijkheid dat diverse ernstige en chronische aandoeningen lange tijd verborgen blijven achter veel voorkomende, goedaardig lijkende klachten en verschijnselen. De verschillen zijn minimaal: een hardnekkige hoest net iets meer prikkelend van karakter dan bij de vele andere hoestende patienten het geval is, een licht veranderd defaecatiepatroon te midden van diverse andere klachten over obstipatie, en niet te vergeten klachten als moeheid, vergeetachtigheid en geringe vermagering.

Bij de interpretatie van meetbare fysisch-diagnostische en laboratoriumgegevens, waarover de huisarts kan beschikken, doet zich een andere moeilijkheid voor. Door de spreiding van waarden, de invloed van leeftijd, geslacht en diverse andere factoren, de nooit geheel te elimineren kans op foutnegatieve en fout-positieve uitslagen, het momentane karakter van het gegeven, door al die factoren is het vaak bijzonder moeilijk te beoordelen of de geconstateerde verschijnselen al dan niet berusten op pathologische veranderingen. Een goed voorbeeld van deze problematiek is de bloeddruk. 
Bloeddrukwaarden zijn permanent aan fluctuatie onderhevig. Ze veranderen met het vorderen van de leeftijd. De betekenis van bloeddrukverhoging als risicofactorvoor hart-vaatziekten is voor mannen en vrouwen niet gelijk.

De betekenis daarvan wordt bovendien in belangrijke mate beinvloed door de aan- of afwezigheid van andere risicofactoren als roken en het serumcholesterolgehalte. Welke betekenis moet gezien deze complexiteit een huisarts nu toekennen aan een een- of tweemaal gemeten bloeddrukwaarde van bijvoorbeeld 150 systolisch en 95 diastolisch?

Op een knelpunt wil ik nog wijzen. Een huisarts heeft niet alleen tot taak zicht te krijgen op de aard en omvang van het in het geding zijnde ziekteproces, maar hij moet ook in staat zijn de patient zelf met zijn gevoelens en met zijn verwachtingen verband houdend met dat ziekteproces te begrijpen. Deze tweeledige taak vindt menwel aangeduid als twee sporen diagnostiek. Idealiter dienen beide sporen te leiden tot een geintegreerde diagnostische omschrijving, welke niet alleen het ziekte etiket, maar ook de gezondheidsrelevante aspecten van de patient en diens leefsituatie bevat. In de praktijk blijken beide sporen echter tot op zekere hoogte in een competitieve relatie tot elkaar te staan.

Enerzijds las ik gevalsbeschrij- vingen, waarbij de in het geding zijnde pathologische processen zo zeer de aandacht opeisten dat de patient zelf geheel op de achtergrond kwam te staan. Anderzijds kwam ik gevallen tegen waarbij juist het aanvoelen van de problematiek en het begrijpen van het gedrag van de patient zodanig domineerde, dat het zicht op de tevens aanwezige pathologie lange tijd verduisterd bleef. De twee sporen leiden blijkbaar nogal eens tot ongelijke beelden die de neiging vertonen elkaar te verdringen.

Gezien de constatering dat de praktische toepassing van de geneeskunde bemoeilijkt wordt door talrijke voetangels en klemmen, ligt het voor de hand om ook het theoretisch fundament van de geneeskundige praktijk nader in ogenschouw te nemen. 
In hoeverre is onze medische kennis, zijnde de basis van onze medische oordelen en beslissingen, op zich misschien een bron van fouten?

$\mathrm{Er}$ is algemene geneeskundige kennis, opgebouwd via wetenschappelijk onderzoek, publicaties, congressen, enz., voortdurend aangevuld en bijgesteld, kortom voortdurend in ontwikkeling. Daarnaast is er, wat we zouden kunnen noemen, individuele geneeskundige kennis; kennis die de arts ten aanzien van een individuele patient heeft opgedaan.

Medische practici lijken zich over de vraag hoe deze beide vormen van kennis tot stand komen weinig zorgen te maken. De algemeen gangbare opvatting is eigenlijk altijd geweest: nauwkeurig en onbevooroordeeld waarnemen leidt tot betrouwbare gegevens. Op grond van die gegevens en met behulp van de reeds verworven inzichten kan een diagnose worden gesteld. De diagnose is het sluitstuk van waarnemen en denken. $Z e$ is tevens de basis van de in te stellen therapie. Tot voor kort vond men deze zienswijze onder woorden gebracht in diverse leerboeken. In het ook nog in de na-oorlogse jaren bekende leerboek "Innere Medizin" bijvoorbeeld schreef de Berlijnse hoogleraar Brugsch bijna lyrisch over "die ewig junge
Quelle der neuen Beobachtungen" en zo vervolgt hij: "Aus den Krankheitszeichen kann die Krankheit erkannt werden, das heiszt, eine Diagnose gestellt werden".

Zo simpel is dat - dacht men.

Met betrekking tot de zogenaamde Fehldiagnoses was de opvatting al even rechtlijnig: een verkeerde diagnose is het gevolg van verkeerd waarnemen of van foutief interpreteren van de gegevens. In beide gevallen is het dus de arts die te kort schiet.

De grondslag van deze zienswijze lijkt solide. Ze is immers geheel in overeenstemming met het zo succesvol gebleken klassiek-natuurwetenschappelijk denken. Terillustratie citeer ik de wetenschapsfilosoof de Vries die in zijn boek "Ontwikkeling van wetenschap" deze denktrant als volgt onder woorden bracht: "Wie goed waarneemt, zijn geest vrijmaakt van vooroordeel en zich vervolgens stechts van logische middelen bedient om de opgedane kennis te verwerken, kan niet anders dan objectieve kennis voortbrengen. Met put immers uit een zuivere bron en verwerkt zijn gegevens met onberispelijke middelen".

Niet iedereen bleek bereid deze zienswijze zonder meer te accepteren. De oogarts Wibaut relativeerde deze opvatting reeds in 
1962 toen hij zijn boek "De methode der geneeskunde" publiceerde. In het jaar 1976 verwierf de Deense gastro-enteroloog H.R. Wulff bekendheid met zijn boek "Rational diagnosis and treatment". Ook hij benadrukte dat objectief waarnemen en verwerken van gegevens met onberispelijke middelen allerminst waarborgen dat een juiste diagnostische conclusie en een bevredigend therapeutisch resultaat tot stand komen. Daarvoor bevat de weg van waarneming naar diagnose - een weg die de huisarts vele keren per dag in vrij hoog tempo heeft af te leggen - te veel voetangels en klemmen.

Het opvallende is nu dat niet alleen de traditionele geneeskundige methode, maar ook de wetenschapstheoretische basis daarvan - in de zin van objectief waarnemen en op grond daarvan inductief redeneren leidt tot juiste conclusies al geruime tijd bloot staat aan twijfel en kritiek.

Als meest felle bestrijder van dit grondschema kan ongetwijfeld de wetenschapsfilosoof Karl Popper worden genoemd. Zijn kritiek, reeds aanwezig in zijn boek "Logik der Forschung", kreeg pas de volle aandacht na het verschijnen van de uitgave "The logic of scientific discovery". Wanneer men kennis neemt van Poppers opvattingen, wordt al snel duidelijk dat Popper de beide pijlers van het grondschema bestrijdt. In de eerste plaats leidt volgens Popper waarnemen niet tot naakte feiten. Waarnemingsuitspraken bevatten onvermijdelijk interpretaties vanuit een bepaald perspectief en samenhangend met bepaalde verwachtingen. In de tweede plaats wijst Popper inductie als constructieprincipe af o.a. op grond van de opvatting dat aan een eindig aantal waarnemingen geen universele uitspraken te ontlenen zijn: "de betrouwbaarheid van kennis schrijft Popper - wordt niet bepaald door de wijze waarop deze is verworven of gefundeerd, maar door de mate waarin deze toetsbaar is. Een absolute empirische basis van wetenschappelijke kennis is er niet. Er is geen rotsbodem waarop wetenschappelijke kennis berust. Wetenschap is mensenwerk". De opvattingen van Popper hebben zoals te begrijpen veel kritiek opgeroepen. Het zijn vooral de wetenschapshistoricus Kuhn en de filosoof Lakatos die de standpunten van Popper op diverse punten hebben bekritiseerd. Beide delen ze echter Poppers kritiek, gericht tegen het klassiek positivistische denken.

Naar mijn mening doen wij in de medische wereld er goed aan de hier vermelde kritiek ter harte te nemen en bij ons medisch denken en handelen als uitgangspunt te kiezen de grondgedachte dat elk diagnostisch eindresultaat een element van onzekerheid in zich 
draagt. Elke diagnose is in wezen een werkhypothese, zij het dat de ene werkhypothese meer aanspraak op vertrouwen kan maken dan de andere.

Gezien deze wetenschapstheoretische discussie zou men zich de vraag kunnen stellen of wetenschappelijke kennis betreffende een individu wel mogelijk is. Is het niet zo dat juist het meest wezenlijke van een mens, n.l. dat wat hem of haar onderscheidt van alle andere mensen, zich onttrekt aan wetenschappelijke oriëntatie? Met deze vraag hebben diverse wetenschapsbeoefenaren zich lange tijd bezig gehouden. Ze komen daarbij - dat zal u niet verbazen - tot volstrekt uiteenlopende standpunten.

Extreem is het standpunt van de empiristische Engelse psycholoog Eysenck. Scientia non est individuorum. Kennis van het individuele valt volgens Eysenck buiten de wetenschap, hoewel hij een mens slechts uniek acht in die zin dat deze een kruispunt is van een aantal kwantitatieve variabelen, maar in die zin is elk object uniek en heeft elke wetenschap in haar toepassing te maken met het unieke. letwat smalend vervolgt hij zijn beschouwing als volgt: "Een ingenieur bouwt geen bruggen in het algemeen, maar altijd een bepaalde brug. Hij past algemene wetten toe op een concreet geval. Dat doet ook de psycholoog als hij een persoon beoordeelt. Het feit dat de psycholoog daarbij de plank vaker misslaat dan de ingenieur bewijst slechts dat wij de wetten die het gedrag van bruggen beheersen, veel beter kennen dat de wetten die het gedrag van mensen beheersen. Het bewijst niet dat mensen unieker zijn dan bruggen". Tot zover de psycholoog Eysenck. Het was de Amerikaan Gordon Allport die bekendheid verwierf met een geheel ander standpunt. Zijn stelling is dat het individu wel degelijk object van wetenschappelijk onderzoek is. Bij het gedrag van mensen gaat het echter niet alleen om beheersen en voorspellen, maar ook om begrijpen. Dat laatste geschiedt niet via statistische generalisatie van gecodeerde ervaringen, maar o.a. door het waarnemen van relaties. Dat laatste vereist een eigen wijze van wetenschapsbeoefening, door Allport aangeduid als de idiografische benadering.

De standpunten van Eysenck en Allport lijken mijlen ver uit elkaar te liggen. Toch is volgens A.D. de Groot, auteur van het bekende boek "Methodologie", de kloof minder groot dan ze lijkt. Met Allport is hij van mening dat het individu wel degelijk voorwerp van wetenschappelijk onderzoek kan zijn. Zo men wil, kan men spreken van een idiografische benadering, mits men zich realiseert dat daarbij dezelfde methodologische regels gel- 
den als bij de z.g. nomothetische wetenschappen. De discussie aangaande de uniciteit doet de Groot af door er op te wijzen, dat het er bij wetenschappelijke exploratie van een individu niet om gaat of deze uniek is, maar of een individualiserende interpretatie in wetenschappelijk opzicht opportuun is.

Het lijkt alsof de discussie rondom de kennis van het individu alleen door psychologen is gevoerd. Dit is niet het geval.

In het jaar 1976 kwam een nieuw tijdschrift op de markt The Journal of Medicine and Philosophy. In het eerste nummer publiceerden twee filosofen Gorovitz en Maclntyre een belangwekkend artikel onder de titel: "Toward a theory of medical fallibility". De geneeskundige praxis - zo stellen de auteurs - steunt op een "science of universais"; dat wil zeggen een wetenschap van aigemene wetten, ontleend aan waarnemingen welke betrekking hebben op meer dan een object resp. individu. Evenwel, artsen hebben in hun praktijk te maken met individuen en niet met groepen en het specifiek individuele van de mens is juist hetgeen buiten het bereik van die wetten valt, gezien de specifieke historie die ieder mens achter zich heeft en die bij elk mens het gedrag mede bepaalt. $\mathrm{Er}$ is daarom - aldus Gorovitz en Maclntyre - behoefte aan een "science of particulars". Onge- twijfeld herkent $U$ in deze stellingname de verwantschap met het reeds vermelde standpunt van Eysenck.

Het belangwekkende van dit artikel en van de polemiek die daar op volgde vind ik persoonlijk niet gelegen in het feit dat het de reeds genoemde wetenschapstheoretische discussie weer oprakelt, maar in het feit dat de auteurs die discussie koppelen aan ons onderwerp de medische feilbaarheid. Voortbouwend op hun zojuist globaal aangeduide wetenschapstheoretische zienswijze komen ze met betrekking tot de medische feilbaarheid tot de volgende visie: Van oudsher bestaat de gewoonte vergissingen te herleiden tot een tweetal foutenbronnen. De eerste foutenbron is onachtzaamheid, variërend van verwijtbare onzorgvuldigheid tot verminderde waakzaamheid onder omstandigheden waarin daarvoor op zijn minst begrip is op te brengen. De tweede bron van fouten is wat we zouden kunnen noemen de wetenschappelijke onwetendheid. Medische handelingen te goeder trouw verricht en steunend op de wetenschappelijke kennis van dat moment, kunnen later blijken gevaarlijke handelingen te zijn geweest. Het voorschrijven van diaethyl-stilboestrol als therapie bij habituele abortus lijkt mij een goed voorbeeld van laatstgenoemde foutenbron; 30 jaar geleden was dit zowel 
wetenschappelijk als empirisch een aanvaarde therapie; anno 1986 als het al zou voorkomen, is het een schoolvoorbeeld van grove onkunde.

Gorovitz en Maclntyre noemen als derde foutenbron de in wetenschappelijk opzicht onkenbaarheid van het specifiek individuele van de patient en als gevolg daarvan de onkenbaarheid van de mate waarin en de wijze waarop het specifiek individuele een rol speelt bij het ontstaan en het beloop van ziekten.

Het artikel van Gorovitz en Maclntyre heeft terecht veel aandacht gekregen. Hun bijdrage aan de theorievorming lijkt bescheiden. Evenwel, de genuanceerdheid waarmee zij het verschijnsel medische feilbaarheid benaderen, verdient bewondering.

Keren we thans terug tot de eerste vraag: hoe komt het dat alarmsignalen soms aan de aandacht ontsnappen?

Op grond van foutenanalyses en rekening houdend met de hier gememoreerde beschouwingen kan de vraag naar mijn mening als volgt beantwoord worden:

$\mathrm{Bij}$ het tot stand komen van onjuiste of onvolledige oordeelsvorming in medische situaties speelt een drietal factoren - dikwijls in combinatie met elkaar - een doorslaggevende rol. Als eerste factor is te noemen de veelheid van situatieve en methodologische knelpunten die de arts voortdurend parten kan spelen. Een tweede factor is de ontoereikendheid en de voorlopigheid van ons medisch kennen. Tenslotte is er natuurlijk als derde factor de medische feilbaarheid als gevolg van menselijk falen, soms begrijpelijk en vergeeflijk, soms in hoge mate te veroordelen. 


\section{De relevantie voor de praktijk.}

Dames en heren, huisartsen en specialisten zijn - zoals dat heet medici practici. Ze interesseren zich voor theoretische beschouwingen, mits de relevantie voor de praktijk niet uit het oog verloren wordt. Dat voert ons tot de tweede vraag, in het begin gesteld: wat zouden we kunnen doen om de zo juist genoem de fouten bronnen zo veel mogelijk te vermijden?

Met het oog op die vraag nog een keer terug naar de luchtvaart. Een paar jaar geleden kreeg ik de gelegenheid een vliegreis te maken, zittend in de cockpit. Met belangstelling keek ik toe, hoe voor de start de gezagvoerder en de copiloot samen een checklist van 40 à 50 punten doornamen. De een noemde de diverse punten op, de ander verrichtte de vereiste controlehandelingen onder het toeziend oog van eerstgenoemde.

Voor mij was dit een illustratie van het gegeven dat structurering noodzakelijk is om gericht te kunnen toetsen.

In de huisartsgeneeskunde heeft men de noodzaak tot structurering van het hulpverleningsproces zoals de huisarts dat in praktijk brengt, onderkend.

In 1975 bracht het Nederlands Huisartsen Genootschap een rapport uit onder de titel "Hoe helpt de dokter?".

Een werkgroep van dit genootschap werkte vervolgens het tweede hoofdstuk daarvan uit tot een rapport: "Methodische werken". Sindsdien hebben diverse huisartsen zich moeite getroost om de in het rapport gepropageerde structurering te verfijnen en aan te vullen. Het boek van Grol, Mesker e.a. over dit onderwerp vormt daarvan een fraai resultaat.

Als tweede ontwikkeling welke bijdraagt tot het rationaliseren en structureren van het diagnostischtherapeutisch proces kan de besliskunde worden genoemd. Het is met name door publicaties van Sturmans en Knottnerus, beiden werkzaam in onze faculteit, dat deze epidemiologisch georiënteerde benadering ingang heeft gevonden. Op basis van epidemiologische gegevens komen o.a. via consensusbesprekingen protocollen en werkafspraken tot stand. Deze ontwikkeling zal, naar we mogen verwachten, in elk geval leiden tot verbetering van het diagnostisch proces. Deze verwachting wordt althans wat de werkafspraken voor E.C.G. onderzoek en leverfunctietests betreft, bevestigd door het enkele dagen geleden met een promotie afgesloten onderzoek van onze medewerker en huisarts Beusmans.

Te verwachten is bovendien dat een aldus bereikte verbetering van diagnostiek zal leiden tot minder fouten.

Evenwel wat vooralsnog ontbreekt, is de toetsing van het ziektebeloop. 
Ter verduidelijking nog even terug naar de theorie.

Betrouwbaarheid van kennis - aldus Popper wordt niet bepaald door de wijze waarop deze is verkregen en ook niet door de wijze waarop ze is gefundeerd, maar door de mate waarin ze bestand is tegen kritische toetsing.

In overeenstemming hiermee is de empirische cyclus, zijnde de methodische weg die een onderzoeker heeft te gaan. Toetsing is daarbij het sluitstuk nadat via inductief waarnemen en deducerend redeneren de hypothese is gevormd.

Naar analogie daarvan is het medisch beslissingsproces te beschouwen als een empirische cyclus waarbij via anamnese en onderzoek waarnemingen tot stand komen en via diagnostische evaluatie een diagnostisch oordeel gevolgd door een therapeutische beslissing, met als sluitstuk de follow-up, dat wil zeggen de toetsing van het beloop. Via methodisch werken en via besliskundige regels brengen we structuur aan in de inductief-deductieve weg leidend tot een diagnostisch-therapeutisch oordeel, maar bij de followup doen we dat tot nu toe niet. Vertaald naar de huisartspraktijk betekent dit dat het anamnestische gesprek, het fysisch-diagnostisch onderzoek en de diagnostisch-therapeutische oordeelsvorming meer en meer gestructureerd ver- lopen, terwijl de follow-up nog geschiedt op geleide van persoonlijke, ongestructureerde ervaring. Afspraken aangaande wel of niet een vervolgconsult en zo ja na hoeveel tijd, vertonen dientengevolge het karakter van ad hoc beslissingen.

Als we de kennistheoretische visie van Popper, door velen ondersteund, toepassen op de diagnostische kennisverwerving - en op grond van de hier naar voren gebrachte theoretische overwegingen is dat alleszins te verdedigen dan kom ik tot de slotsom dat gezien het voorlopige karakter van onze diagnostische oordelen, de structurering van het hulpverleningsproces niet alleen het traject anamnese-onderzoek - diagnose - therapie dient te omvatten, maar ook het follow-up traject, dat wil zeggen het ziektebeloop.

Een diagnostisch oordeel is immers niet alleen een uitspraak omtrent de oorsprong resp. ontstaanswijze van de ziekteverschijnselen, het is ook een prognostische uitspraak. Een voorbeeld; een ietwat verouderd voorbeeld misschien: een huisarts bezoekt een kind dat koorts heeft, duidelijk verkouden is en zich ziek voelt. De huisarts vindt bij onderzoek van het mondslijmulies enkelezgn. Koplikse vlekjes en komt op grond van deze en andere bevindingen tot de diagnose mazelen. Impliciet spreekt hij met die diagnose de verwachting 
uit dat zich bij het kind op korte termijn een exantheem zal ontwikkelen en dat de ziekteverschijnselen daarna geleidelijk zullen afnemen. De huisarts kan de verwachting expliciet maken door niet alleen de diagnose mazelen, maar ook de voorspelling omtrent het ziektebeloop tegenover de moeder uit te spreken.

Het doen van voorspellingen is echter een hachelijke bezigheid, zoals iedereen weet.

Diverse beroemdheden, die hun sporen alleszins hadden verdiend, zijn juist met het uitspreken van voorspellingen de mist ingegaan. Ik noem $U$ twee beroemde voorbeelden. In 1932 sprak Einstein de volgende woorden: "Er bestaat niet de geringste aanwijzing dat kernenergie ooit werkelijkheid zal worden".

In 1931 verklaarde von Hindenburg: "Hitler is een rare snuiter die nooit kanselier zal worden; de beste positie waarop hij mag hopen is hoofd van de posterijen".

Als $U$ geïnteresseerd bent in meer van dergelijke markante miskleunen, dan kunt $U$ die lezen in een boekje, getiteld "The experts speak".

Met prognostische uitspraken stelt een arts zich kwetsbaar op. Toch zou een arts meer dan nu geval lijkt zich moeten wagen aan prognostische uitspraken. Op het congres van het Nederlandse Huisartsen Genootschap in 1982 hield de Nijmeegse hoogleraar huisartsgeneeskunde $\mathrm{H}$. van der Velden een interessante voordracht over dit onderwerp met de titel: "Diagnose of prognose".

Een citaat uit die voordracht lees ik $U$ voor:

"Hippocrates beschouwt in zijn Prognosticon het beoordelingsaspect over het verloop, het belangrijkste criterium voor de kwaliteit van de arts. Het is de prognose, die de patient in feite interesseert. Het is de enige uitspraak van de arts, die door de patient op juistheid is te toetsen".

Elk ziekte- resp. klachtenbeloop bevat elementen waaraan een impliciet aanwezige of expliciet geformuleerde prognose kan worden getoetst. Het gaat erom de meest relevant elementen te selecteren en vervolgens de betekenis van die elementen voor het diagnostisch-therapeutisch oordeel waarop de prognose is gebaseerd zichtbaar te maken. Een logische daaropvolgende stap is het aangeven van de beslissingen die up grond van deze evaluatie in aanmerking komen: herziening van het diagnostisch oordeel, bijstelling van de therapie, overgaan tot verwijzing of wat dan ook.

Ik ben mij bewust dat wat ik hier in enigszins zwaarwichtig aandoende formuleringen naar voren breng in feit door elke huisarts wordt toegepast. Wanneer de huisarts het even te voren genoemde zieke 
kind enkele dagen later opnieuw bezoekt en constateert dat het exantheem inderdaad is uitgebroken, maar het kind nog ziek en de koorts hoog blijft, dan zal hij daarin een bevestiging van zijn diagnostisch oordeel zien, maar hij zal bovendien de dreiging van een zich ontwikkelende bronchopneumonie in zijn diagnostische overweging betrekken. Waar ik nu voor pleit, is dat ook met betrekking tot het vervolgen van het ziektebeloop ongestructureerde ervaring in gestructureerde kennis wordt omgezet en vervolgens uitmondt in acceptabele, praktische richtlijnen. Het ideale mag daarbij niet de vijand van het goede worden. Bij diverse gezondheidsproblemen is de diagnose gelukkig met redelijke zekerheid te stellen en ligt de therapie voor de hand. De wenselijkheid van structurering is dan ook niet bij alle problemen even groot.

We zouden drie categorieën kunnen onderscheiden.

Er is - zoals gezegd-een categorie gezondheidsproblemen waarbij het vormen van een diagnostisch oordeel zonder moeilijkheden tot stand komt en een verantwoorde therapie voorhanden is. Observeren van het ziektebeloop is primair van belang om het effect van de therapie te beoordelen, zij het dat de noodzaak tot revisie van het diagnostisch oordeel altijd aanwezig blijft.
Binnen deze categorie bestaat weliswaar behoefte aan structurering, maar daarbij moet worden opgemerkt dat dit niet voor alle problemen binnen deze categorie het geval is. Door het Nijmeegs Universitair Huisartsen Instituut is op dit terrein een goede start gemaakt. Het landelijk protocolproject, mogelijk gemaakt door de steun van het Preventiefonds, is in dit verband te beschouwen als een veelbelovende voortzetting.

Een tweede categorie van gezondheidsproblemen wordt gekenmerkt doordat hier de dreiging, dat er een ernstig lijden in het spel is, nadrukkelijk aanwezig, althans niet met voldoende zekerheid uit te sluiten is. De arts ziet zich in die gevallen als regel genoodzaakt zijn strategie af te stemmen op die ernstige aandoening, ook al lijkt een andere, minder ernstige aandoening waarschijnlijker. Wulff noemt dit de minimax strategie. Onder het motto "better safe than sorry" komt het voor dat een huisarts een patient met acute buikklachten naar het ziekenhuis verwijst niet omdat hij de diagnose acute appendicitis de meest waarschijnlijke acht, maar omdat hij het risico dat er toch een appendicitis in het spel is, onaanvaardbaar groot vindt. Analoog is de situatie waarin een huisarts een hoestende, koortsige patient anti- 
biotica voorschrijft omdat hij het risico toch een beginnende pneunomie aan te zullen treffen, incalculeert ondanks ontbreken van fysisch-diagnostische verschijnselen. Het is duidelijk dat krampachtige toepassing van deze strategie leidt tot ongewenst defensief handelen met alle nadelige gevolgen van dien. Het wordt dan schieten met een kanon op een mus en dat is niet alleen een omslachtige, maar ook een kostbare bezigheid. Ook in deze categorie is het daarom van belang dat normen en beslisregels worden ontwikkeld. De met het oog op ons onderwerp interessantste categorie is de categorie van gezondheidsproblemen die de huisarts geneigd is te taxeren als niet ernstig, evenwel zonder dat hij met een redelijke mate van zekerheid tot een ziektediagnose komt. In deze categorie bevinden zich klachten als moeheid, nervositeit, hoofdpijn, vage buikklachten, lage rugklachten, dikwijls in uiteenlopende combinaties. Het beloop is meestal onvoorspelbaar en bij de presentatie van de klachten klinkt een emotionele ondertoon merkbaar door. Het fysisch-diagnostisch en aanvullend onderzoek brengt als regel nauwelijks afwijkende gegevens aan het licht en toch is de dreiging van een latent ernstig. progressief lijden op de achtergrond aanwezig. In deze categorie vinden we ook diagnostische di- lemma's van meer acute aard zoals plotseling opgekomen pijn rechts onder in de buik: geen défense maar toch ....; een in korte tijd benauwd geworden kind: pseudokroep of misschien toch een epiglottitis; een man met een rood pijnlijk oog: conjunctivitis of toch een acuut glaucoom?

Het is vooral bij de problemen in deze categorie dat een huisarts het gevaar loopt in een valkuil terecht te komen. Daarom dient juist bij deze dillema's de structurering van het hulpverleningsproces gedurende het eerste consult gevolgd te worden door toetsing van het voorlopige diagnostische oordeel tijdens de follow-up periode, dat wil zeggen de periode die begint zodra het eerste consult is afgesloten.

Een huisarts is gewend de juistheid van zijn diagnostisch oordeel en het effect van de ingestelde therapie te bewaken door met de patient een afspraak te maken voor een volgend contact. Tijdens dat contact zal hij in elk geval de patient vragen naar diens ervaringen en zal hij zijn onderzoeksbevindingen vergelijken met die van het eerste contact. In feite is dit een vorm van empirische toetsing. Het is echter een ongestructureerde toetsing in die zin dat te voren opgestelde toetsingsregels en criteria aan de hand waarvan het diagnostisch oordeel bevestigd of weerlegd wordt geacht, ontbreken. 
Een eerste stap op weg naar structurering zet de huisarts door tijdens het eerste contact vast te leggen op welke punten tijdens het tweede contact in elk geval onderzoek zal plaatsvinden. In veel gevallen gebeurt dit ook, soms op geleide van een speciale werkkaart zoals bij zwangerschapsonderzoek en bij de begeleiding van diabetespatienten.

Een volgende stap, tot nu toe minder gebruikelijk, is het opstellen van criteria aan de hand waarvan de huisarts tijdens het tweede contact gaat beslissen of hij zijn diagnostisch oordeel als basis van zijn handelen zal handhaven of niet. Bij de patient met buikklachten kan hij bijvoorbeeld voor zich zelf, maar ook met de patient vastleggen dat het oordeel "geen acute buik" zal worden herzien, wanneer twee uur na het eerste contact bepaalde verschijnselen blijken te zijn opgetreden of de pijn niet duidelijk is afgenomen. Bij een patient met naar het oordeel van de arts nerveus funktionele klachten kan worden vastgelegd dat dit oordeel als uitgangspunt van behandeling zal dienen op voorwaarde dat bij periodieke controle van hart, longen, bloed en urine geen bevindingen aan het licht komen die herziening van dat oordeel vereisen. Ook in medische situaties zullen gevallen, waarin signalen van dreigend gevaar niet of niet tijdig worden onderkend, altijd blijven voor- komen. Het aantal keren dat zo iets plaatsvindt, kan echter teruggedrongen worden door - en dat is mijn antwoord op de tweede vraag - evenals in het anamnestisch gesprek en in het fysisch-diagnostisch onderzoek ook structuur aan te brengen in de vervolgcontacten. Richtlijnen, werkafspraken, consensusuitspraken, protocollen, tot stand komend op basis van besliskundige regel, kunnen ook hier goede diensten bewijzen.

Een dergelijke structurering kan in nauwe samenwerking met huisartsen en specialisten stap voor stap worden ontwikkeld grotendeels op basis van reeds beschikbare kennis en ervaring. Waar een eenduidig antwoord niet voorhanden is, zal de noodzaak van wetenschappelijk onderzoek voelbaar worden. Als regel zal het dan gaan om patientgebonden onderzoek, gericht op het beloop van ziekten zoals zich dit in opeenvolgende fasen voltrekt.

De capaciteitsgroep Huisartsgeneeskunde zal op dit omvangrijke werkgebied haar aandeel stellig kunnen leveren. Gezien de deels afgesloten, deels in voorbereiding zijnde academiseringscontracten en gezien de aanwezigheid van het diagnostisch coördinerend centrum in het academisch ziekenhuis Maastricht lijken de voorwaarden gunstig. Noodzakelijke voorwaarden zijn echter tijd en faciliteiten zowel voor werkzaamheden als 
het houden van consensusbesprekingen met huisartsen, het in de praktijk uittesten en bijstellen van concept richtlijnen enz., kortom voor gezondheidszorgontwikkeling, als voor onderzoek en natuurlijk ook onderwijs. De noodzakelijkheid van een evenwichtige combinatie, gezondheidszorgontwikkeling en onderwijs/onderzoek wordt in alle academische ziekenhuizen als vanzelfsprekend beschouwd. Deze noodzaak is natuurlijk onverminderd aanwezig als het gaat om het sluiten van academiseringscontracten met huisartsen. Ik heb de indruk dat de neiging bestaat hierop af te dingen en daarover maak ik mij bezorgd. 


\section{De relevantie voor het onderwijs}

Dames en heren, als hoogleraar behoor ik tot het onderwijzend personeel. Daarom tot slot iets over de betekenis van het besprokene voor het medisch onderwijs. Onze toekomstige artsen behoren als basiservaring van de universiteit mee te krijgen dat de weg van klacht naar diagnose, van diagnose naar therapie en van therapie naar genezing vaak moeilijk begaanbaar is. Met het oog daarop moeten zij zich aan de hand van talrijke leerervaringen bekwamen in het tijdig opvangen van alarmsignalen en het onderkennen van knelpunten. Het is duidelijk dat dit via praktisch medisch onderwijs moet gebeuren. In de omgang met de patient en met de opleider moet de toekomstige arts bovendien zich bewust worden dat diagnostische oordelen per definitie onzeker, onvolledig en voorlopig zijn, dat bijstelling van die oordelen voortdurend aan de orde is en dat empirische toetsing daarom niet kan worden gemist. Wil een stage de mogelijkheid tot die bewustwording verschaffen dan zal deze op zijn minst aan een drietal voorwaarden moeten voldoen. Het zal een langdurige stage moeten zijn, want het procesmatig karakter van een ziekte en dus ook voor de daaraan gerelateerde oordeelsvorming wordt pas goed duidelijk op geleide van meerdere contacten met dezelfde patient. De studenten zullen hun bevindin- gen en hun oordelen moeten vastleggen, want alleen via getrouwe verslaglegging kan duidelijk worden waar en hoe correctie en bijstelling geboden zijn.

De studenten zullen hun bevindingen en hun vragen regelmatig moeten bespreken met opleiders, die daarvoor open staan.

Als er iets is waarop ik met voldoening terugzie, dan is dat het praktisch medisch onderwijs zoals dat aan onze faculteit in huisartspraktijken plaatsvindt. De uitstekende coördinatie van Tonja Mol, de inzet van een kleine groep huisartsbegeleiders en niet te vergeten het enthousiasme en de toewijding van een vaste kern van huisartsopleiders hebben het p.m.o.-H gemaakt tot een stage welke hoge waardering geniet van de studenten en bewondering oogst van bezoekers uit binnen- en buitenland. Richtlijnen, werkafspraken e.d. welke structuur brengen in het vormen van diagnostische oordelen en in het empirisch toetsen daarvan zullen in deze stage een nuttig toepassingsveld vinden.

Enkele maanden geleden hebt $U$ kennis kunnen nemen van de aankondiging dat overeenkomstig richtlijnen van de Europese Gemeenschap de opleiding tot huisarts met ingang van januari 1988 een tweejarige opleiding zal worden. Velen van ons hadden liever een driejarige opleiding gezien. Dat 
neemt echter niet weg dat ook een verlenging tot twee jaar gezien moet worden als een belangrijke stap vooruit. Vooruitlopend op deze beslissing houdt een landelijke curriculumcommissie zich reeds geruime tijd bezig met het formuleren van de te bereiken leerdoelen en met de opzet van een daarop afgestemd onderwijsprogramma. Tot mijn genoegen las ik in de door deze commissie uitgebrachte rapporten dat de aandacht niet alleen uitgaat naar klachten en aandoeningen als zodanig, maar ook naar het daaraan ten grondslag liggende hulpverleningsproces. Ik hoop dat het onderwerp vervolgcontacten, daarin begrepen toetsing van diagnostische oordeelsvorming daarin een belangrijke plaats zal vinden.

Dames en heren, artsen - huisartsen niet uitgezonderd - maken fouten. Dat wist $U$ al en de artsen weten het eveneens. Wat we ook weten, dat is dat veel van de fouten berusten op een verkeerde taxatie van verschijnselen en onjuiste oordeelsvorming met als gevolg daarvan een verkeerde beslissing.

Deze vaststelling dwingt ons tot intensieve bestudering van vragen: hoe komen onze oordelen tot stand, hoe betrouwbaar zijn ze en op welke wijze is die betrouwbaarheid te verhogen?

Door ons intensief met deze vragen bezig te houden, moet het mo- gelijk zijn medische beslissingen meer te funderen op rationele overwegingen dan nu veelal het geval is. Het besef dat bij medische beslissingen altijd ook irrationele factoren meespelen, doet daaraan niets af. Integendeel, het dwingt ons juist rationele en irrationele factoren zo goed mogelijk van elkaar te onderscheiden. Doen we dit niet, dan dreigen we te verzanden in situaties, waarin onvoldoende duidelijk is aan welke beweringen wel en aan welke geen bewijskracht moet worden toegekend. Dat geldt uiteraard niet alleen voor de geneeskunde.

Toen eens een van moord beschuldigde verdachte hardnekkig bleef ontkennen en de rechter opmerkte dat hij twee personen kon laten verschijnen die bereid waren te verklaren dat ze hem de moord hadden zien plegen, antwoordde de verdachte dat hij van dat argument allerminst onder de indruk was, aangezien hij met gemak honderd personen kon laten verschijnen die bereid waren te verklaren dat ze het niet gezien hadden. 
Dames en heren, met groot genoegen zie ik terug op de periode die ik hier aan de medische faculteit van de Rijksuniversiteit Limburg heb doorgebracht. Als lid van de eerstbenoemde groep hoogleraren, de z.g. kernstaf, kreeg ik de gelegenheid in diverse functies mee te werken aan de opbouw van de faculteit. Deze variatie van functies en de daaruit voorvloeiende confrontatie met telkens nieuwe problemen heb ik als zeer stimulerend ervaren. Het gevolg was echter wel dat ik me met mijn eigen vakgebied, de Huisartsgeneeskunde, veel minder heb kunnen bezighouden dan ik had verwacht en gewild. Ik wil $U$ wel zeggen dat ik meermalen met enige jaloezie heb gekeken naar mijn biomedische en klinische collega's die hun bijdrage aan de faculteit kunnen leveren vanuit hun laboratorium of kliniek. Ook de huisartsgeneeskunde heeft een eigen werkplaats nodig. Een dergelijke basale voorziening is noodzakelijk voor de ontwikkeling van het vakgebied, want ook voor de huisartsgeneeskunde geldt het gezegde:"An ounce of practice is more than a ton of theory". Het is bovendien noodzakelijk voor een faculteit, die gezien haar profilering meer dan andere medische faculteiten tot taak heeft zich bij onderwijs en onderzoek te laten leiden door gezondheidsproblemen van de algemene praktijk.
Ik wens mijn opvolger en alle medewerkers van de capaciteitsgroep Huisartsgeneeskunde toe dat in het kader van de ontwikkelingen op het terrein van wat wij academisering noemen, binnenkort voor hen een situatie zal ontstaan die de vergelijking met de situatie in de kliniek kan doorstaan. Het is na het uitspreken van deze wens dat ik op de gebruikelijke wijze wil eindigen met de woorden "ik heb gezegd". 


\section{Geraadpleegde literatuur.}

- Bremer, G.J., e.a., Inleiding tot de huisartsgeneeskunde. Stenfert Kroese, 1974.

- Vries, G., de, De ontwikkeling van wetenschap; een inleiding in de wetenschapsfilosofie.

Wolters-Noordhoff, Groningen, 1985.

- Wibaut, F., De methode der geneeskunde.

Erven, Bohn, Haarlem, 1962.

- Wulff, H.R., Principes van klinisch denken en handelen.

Bohn, Scheltema \& Holkema, Utrecht, 1980.

- Popper, K.J., The logic of scientific discovery. Londen, 1968.

- Strien, P.J., van, Kennis en communicatie.

Erven, J. Bijleveld, Utrecht, 1966.

- Gorovitz, S. en MacYntyre, A., Toward a theory of medical fallibility. Journal of Medicine and Philosophy, 1 (March 1976): 51-71.

- Grol, R.P.T.M., e.a., Huisarts en onderling toetsing.

Bohn, Scheltema \& Holkema, Utrecht, 1986. 